\title{
The role of heterotrimeric $G$ proteins in the control of the development of symbiosis of leguminous plants with nodule bacteria
}

\author{
Bovin A.D., Pavlova O.A., Kustova D.V., Leppyanen I.V., Dolgikh E.A. \\ ARRIAM, Saint Petersburg, Russia \\ E-mail:dol2helen@yahoo.com
}

\begin{abstract}
Key message. In this work, we analyzed the localization and effect of suppression of gene expression of $\beta$-subunits of $G$ proteins on nodule formation. The possible interaction of $\alpha$ - and $\beta$-subunits with a set of signal regulators in vitro was revealed.
\end{abstract}

Keywords: heterotrimeric G-proteins, nodulation, signaling pathways, legumes

Heterotrimeric $\mathrm{G}$ proteins are known regulators of animal signaling pathways, but evidence of the presence of $\mathrm{G}$ proteins in plants was obtained only a few years ago. The interest in studying heterotrimeric plant G-proteins as master regulators of signaling pathways is due to their interaction with phospholipases $\mathrm{C}$ and $\mathrm{D}$, protein kinases, as well as the effect on reactive oxygen species formation and calcium metabolism in cells.

The aim of our work was to elucidate the role of heterotrimeric $\mathrm{G}$ proteins in the control of nodulation in leguminous plants Pisum sativum and Medicago truncatula. To this end, the effect of RNA interference suppression of the expression of the Gbetal and Gbeta2 genes encoding the $\beta 1$ - and $\beta 2$-subunits of the G protein in transgenic roots of $P$. sativum and $M$. truncatula on the development of symbiosis was evaluated. To identify possible targets of action in the cell, an analysis of the interaction of various $\alpha$-, $\beta$ - and $\gamma$-subunits of G proteins with new and known components of the signaling pathway activated by the plant reception of Nod-factor rhizobia signal molecules by co-immunoprecipitation. The localization of the expression of Gbeta1 and Gbeta2 genes in plant roots in response to inoculation using reporter constructs pMtGbeta1::Tomato and pMtGbeta2::Tomato containing the promoters of the corresponding genes was studied.

As a result, it was shown that suppression of Gbetal gene expression in the roots of P. sativum and M. truncatula led to a significant decrease in nodule number compared to control plants transformed with the vector containing the glucuronidase gene (GUS control). Suppression of Gbeta2 expression in the roots led to disturbances in the primordia formation and further development of nodules and lateral roots in P. sativum and M. truncatula. This effect may be associated with alterations in the synthesis and/or reception of auxins. The possible interaction of pea $\alpha 2$-subunit with the kinase domain of the receptor for Nod factors necessary for initiating the development of symbiosis was shown by co-immunoprecipitation. In addition, the interaction of the $\beta 1$-subunit of pea $G$ protein with annexin 4 , a possible regulator of the signaling pathway activated by Nod factors, was revealed.

The research was supported by RSF (project No. 16-16-10043ח).

\section{Роль гетеротримерных G-белков в контроле развития симбиоза бобовых растений с клубеньковыми бактериями}

Бовин А.Д., Павлова О.А., Кустова Д.В., Леппянен И.В., Долгих Е.А. ФГБНУ ВНИИСХМ, Санкт-Петербург, Россия

\begin{abstract}
Аннотация. В данной работе изучены локализаџия и влияние подавления экспрессии генов $\beta$-субъединиц $G$-белков на клубенькообразование. Выявлено возможное взаимодействие $\alpha$ - и $\beta$-субъединиц с рядом сигнальных регуляторов развития симбиоза.
\end{abstract}

Ключевые слова: гетеротримерные G-белки, клубенькообразование, сигнальные пути, бобовые растения

Гетеротримерные G-белки являются известными регуляторами сигнальных путей у животных, но только несколько лет назад были получены доказательства наличия G-белков у растений. Интерес к изучению гетеротримерных G-белков растений как мастер-регуляторов сигнальных путей обусловлен их взаимодействием с фосфолипазами C и D, протеинкиназами, а также влиянием на образование активных форм кислорода и кальциевый обмен в клетках.

Целью нашей работы явилось выяснение роли гетеротримерных G-белков в контроле процесса клубенькообразования у бобовых растений - Pisum sativum и Medicago truncatula. Для этого было оценено влияние подавления методом РНКинтерференции экспрессии генов Gbeta1 и Gbeta2, кодирующих $\beta 1$ и $\beta 2$-субъединицы G-белка, в трансгенных корнях $P$. sativum и M. truncatula на развитие симбиоза. Для выявления возможных мишеней действия в клетке проведен анализ взаимодействия различных $\alpha$-, $\beta$ - и $\gamma$-субъединиц G-белков с новыми и известными компонентами сигнального пути, активируемого при рецепции растениями сигнальных молекул ризобий Nod-факторов, методом ко-иммунопреципитации. Изучена локализация экспрессии генов Gbetal и Gbeta2 в корнях растений в ответ инокуляцию при помощи репортерных конструкций pMtGbeta1::Tomato и pMtGbeta2::Tomato, содержащих промоторы изучаемых генов.

В результате было показано, что подавление экспрессии гена Gbetal в корнях P. sativum и M. truncatula привело к существенному снижению образования клубеньков по сравнению с контрольными растениями, трансформированными вектором с геном глюкуронидазы (GUS - контроль). Подавление экспрессии Gbeta2 в корнях P. sativum и M. truncatula привело к нарушениям закладки примордиев и дальнейшего развития клубеньков и боковых корней у $P$. sativum и $M$. truncatula. Данный эффект может быть связан с изменением синтеза и/или рецепции ауксинов. Методом коиммунопреципитации было показано возможное взаимодействие $\alpha 2$-субъединицы гороха с киназным доменом рецептора к Nod-факторам, необходимого для инициации развития симбиоза. Помимо этого, выявлено взаимодействие $\beta 1$-субъединицы G-белка гороха с аннексином 4 - возможным регулятором сигнального пути, активируемого Nod-факторами.

Исследование поддержано грантом Российского научного фонда (проект № 16-16-10043П). 